\title{
Obong Victor Attah International Airport and Its Contributions to the Income of the Host Communities in Akwa Ibom State, Nigeria
}

\author{
Ihuoma Blossom Adindu ${ }^{1 \star}$ and Raimi Morufu Olalekan ${ }^{2 \star}$ \\ ${ }^{1}$ Department of Geography and Natural Resources Management, Faculty of Social Sciences, University of Uyo, Uyo, Akwa Ibom State, \\ Nigeria \\ ${ }^{2}$ Department of Community Medicine, Environmental Health Unit, Faculty of Clinical Sciences, Niger Delta University, Wilberforce Island, \\ Bayelsa State. Nigeria
}

\section{Article Info \\ *Corresponding authors: Ihuoma Blossom Adindu \\ Department of Geography and Natural \\ Resources Management \\ Faculty of Social Sciences \\ University of Uyo \\ Uyo, Akwa Ibom State \\ Nigeria \\ E-mail: blossomcheries@yahoo.com}

\section{Raimi Morufu Olalekan \\ Department of Community Medicine \\ Environmental Health Unit \\ Faculty of Clinical Sciences \\ Niger Delta University \\ Wilberforce Island, Bayelsa State \\ Nigeria \\ E-mail: morufu.raimi@waldenu.edu}

Received: December 19, 2018

Accepted: December 27, 2018

Published: December 31, 2018

Citation: Adindu IB, Raimi MO. Obong Victor Attah International Airport and Its Contributions to the Income of the Host Communities in Akwa Ibom State, Nigeria. Int J Earth Sci Geol. 2018; 1(1): 46-50. doi: 10.18689/ijeg-1000105

Copyright: @ 2018 The Author(s). This work is licensed under a Creative Commons Attribution 4.0 International License, which permits unrestricted use, distribution, and reproduction in any medium, provided the original work is properly cited.

Published by Madridge Publishers

\begin{abstract}
Rationale

From infrastructure to culture to economic opportunity, harnessing the power of development for global progress is imperative interestingly. The aviation industry all over the world is credited for a considerable effect in terms of development even in the face of airline mishaps that wreak havoc on the industry. Airports and its corresponding infrastructure have been linked to the growth and development of many places around the world.
\end{abstract}

\section{Objective}

However, this research work measured the contributions of the Obong Victor Attah International Airport to the social and economic life of host communities of Uruan, Okobo and Nsit-Atai. LGA's in Akwa-Ibom State.

\section{Method}

A buffer was used to demarcate the study into zones and a systematic sampling technique was employed in selecting the households to be sampled. The sample size composed of 400 respondents and this was determined from the population of the host communities using the Taro Yamane formula. Data needed for this study was obtained from questionnaires administered to the 400 respondents. Secondary data was collected from Obong Victor Attah International Airport Development Company. Data collected were analyzed using; percentages, charts, maps and simple linear regression statistical tools. The hypothesis formulated was tested using simple linear regression analysis, the null hypothesis which stated that airport does not significantly impact income.

\section{Results}

Results from the analysis revealed that $10 \%$ and $13 \%$ of the total number employed in 2013 and 2017 respectively were from the host communities and that the communities were within monthly mean income of 29,645 Naira. From this result it is here inferred that, Obong Victor Attah International Airport is not the major determinant of income in the study area.

\section{Conclusions/Recommendations}

It was therefore recommended that the Government should improve their socioeconomic well-being. Also, it is concluded that sustainable income is visible and possible if a mechanism exists that guarantees the security and flow of income either ways and that a good, active public relations program is a necessity. 
Keywords: Income; Economic opportunity; Well-being, Socio-economic; Host Communities; Development; Aviation Industry.

\section{Introduction}

Half the world's population currently lives in urban centers. These cities are collectively responsible for three-fourths of global economic output. As urbanization intensifies, communities are impacted by the global challenges and opportunities of sustainable development. However, socioeconomic development stresses progress in terms of economic and social factors which range from income to wealth and quality of life which may be health related or environment related. The purpose of economic development is to improve the social and material well-being of all individuals and social institutions with the sole aim of achieving the highest level of human development [1-4]. For socio-economic development to be successfully achieved, certain drivers must come to play. One of such drivers amongst all others is infrastructure. However, many studies have shown income to be very paramount in assessing economic impact [4-9]. Globally, Airports create thousands of jobs and generate considerable income and contribute significantly to the total economic activity of its surrounding region [4]. Various studies including Intervista (2014); [1,5,7] employed methods such as employment survey, IMPLAN model, survey questionnaire and airport statistics to support this assertion.

Intervista [3] conducted a study to estimate the economic impact of Hamilton international airport USA. Total employment survey was used to classify the total employments and average wages paid by business type. From their analysis airport paid wages worth, 151 million and generated 2,760 jobs. Relatedly, [10] prepared a report on the South Carolina Economic Impact of Aviation. The study used the input-output model with multipliers specific to the South Carolina Airport to derive the total economic impacts attributable to the Airports. He used jobs and wages as measures of economic impact. IMPLAN model provided information used to calculate the total earnings from the jobs created by the Airport. Result of the analysis from the payroll revealed that each employee earns an annual salary of $\$ 39,600$ per FTE (full time equivalent with the average civil aviation airport full time equivalent earning $\$ 35,000$ and military employee $\$ 41,800$.

$\mathrm{ACl}$ [1] also assessed the economic contribution of European Airports. Like other studies income from jobs was also used as an indicator of economic impact. Data was from 125 Airports representing $71 \%$ of the traffic in Europe. A survey questionnaire was used to collect data on the measures of economic impact which includes annual payroll or average salary per employee. Analysis revealed that the total employment jobs from the European Airports received an estimated 68.5 billion Euros in income (wages, salaries, bonuses and other remuneration). The study inferred that this figure is considerably higher than the average income in the overall economy which reflects that the large numbers of highly skilled positions are supported by airport activity.
Furthermore, Martin Associates [5] measured the economic impact of airport generated by the General Mitchell International airport US, using 2005 as the base year for analysis. The income generated from the employees of the five major airport system (airport service, freight transportation, passenger ground transportation, contract construction/ constructing services and visitor industry services) were used as one of the major measures of economic impact. To achieve the set aim, the impacts were measured based on interviews, local economic data and airport statistics which showed that a total of 6,341 direct employees earned an estimated total of $\$ 262.7$ million in wages and salaries. The income impact was estimated to be based on the average wages and salaries multiplied by the corresponding job impact in that category.

Huderek-Glapska [2] assessed the employment and income benefit of Warsaw airport Poland.

Input-output model was used to measure the economic benefit of airport operation majorly in terms of employment and income. The added value generated on the income by the airport operator, the main handling agents (Warsaw airport services, LOT caterers) and the biggest airline (Pilot) was calculated on basis of their financial statement. When there was no access to 2011 data, 2010 data was taken into rate of the value of the added growth with the consideration of the type activity. The added values generated by the other companies were calculated on the basis of the number of people employed and the average added value generated by an employee with the consideration of the type of activity. The data was made available by GUS (The main statistical office) analysis revealed that companies operating on site or in the surrounding area of Warsaw airport have generated 404 Euro income in the economy of Warsaw and the region. The following objectives were the targets of this paper; to assess the extent to which Airport has generated income for the host communities.

\section{Questions}

1. How has the airport influenced income generation of host communities?

\section{Hypothesis}

The following null hypothesis would be tested;

$\mathbf{H}_{\mathrm{o}}=$ Obong Victor Attah International Airport does not significantly impact income.

\section{Materials and Methods}

\section{Study area: location}

The Obong Victor Attah International Airport is an Airport in Akwa Ibom State, Nigeria, this Airport is hosted by three (3) local governments which constitute the study area. They are Okobo, Nsit Atai, and Uruan local governments. The area is located within the coordinates $8.00 \mathrm{E}-8.50 \mathrm{E}$ and $4.500 \mathrm{~N}$ and $4.550 \mathrm{~N}$. 


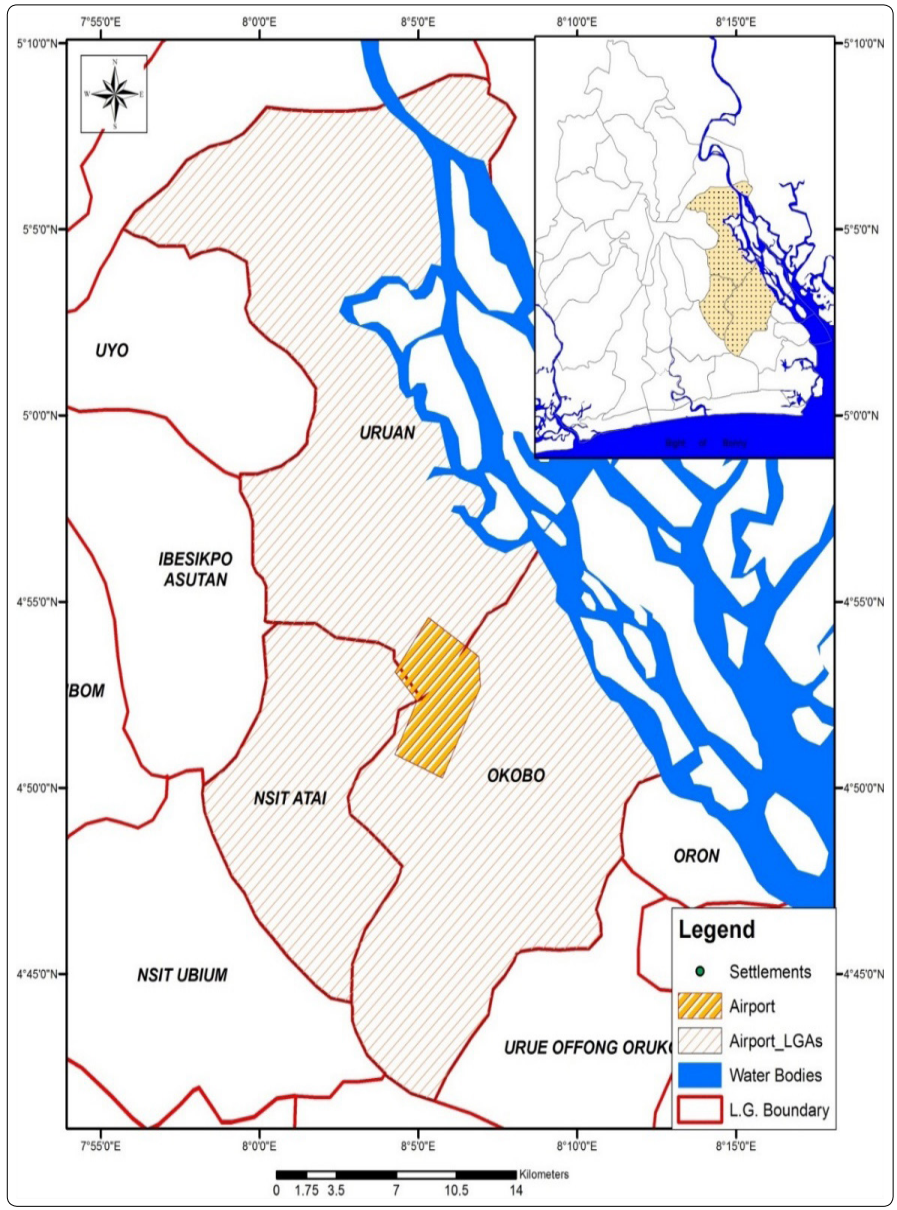

Figure 1. Akwa Ibom State Showing the Study Area.

\section{People and Population}

The people are mainly Ibibio's, with Ibibio language as the major spoken language. Ibibio constitute the largest ethnic group in Akwa Ibom state. According to projected population of 2015 by the Ministry of Economic Development Uyo, Akwa Ibom State, Nsit-Atai has a population of 99,164, with 50,242 males and 48,922 females. Okobo has a population of 138,828 ; made up of 70,790 males and 68,038 females. Uruan, has a population of 95,576 this is composed of 48,920 males and 46,656 females. Population of the study area was vital to the study because population is pivotal to the development of any region.

\section{Sampling Procedures and Methods of Data Collection}

\section{Sampling procedures}

Table 1. Sample Population.

\begin{tabular}{|l|l|l|l|}
\hline $\begin{array}{l}\text { Local } \\
\text { Governments }\end{array}$ & $\begin{array}{l}\text { Projected } \\
\text { Population (2017) }\end{array}$ & $\begin{array}{l}\text { Percentage } \\
\text { Represented (\%) }\end{array}$ & $\begin{array}{l}\text { Villages Projected } \\
\text { Population (2017) }\end{array}$ \\
\hline Okobo & 134,264 & $35 \%$ & EgbghiEta - 1,848 \\
\hline & & & Nung Atai - 7,232 \\
\hline & & & Ammong - 20,534 \\
\hline & & & Total - 29614. \\
\hline Uruan & 153,101 & $39.9 \%$ & Ekpene Ukim - 14,774 \\
\hline & & & IshietEkim - 4,657.12 \\
\hline & & & Ndon Ebom - 17,046 \\
\hline & & & Esuk Inwang - 2,199 \\
\hline & & & Total 38676. \\
\hline
\end{tabular}

\begin{tabular}{|l|l|l|l|}
\hline Nsit Atai & 95,903 & $25.02 \%$ & lkot Inyang - 948 \\
\hline & & & Idibia - 21,299 \\
\hline & & & Ndon Ekpe - 698 \\
\hline & & & Ikot Ekpo - 587w \\
\hline & & & Total - 23,533.48 \\
\hline Total & 383,268 & $99.9 \%$ & $91,822.92$ \\
\hline
\end{tabular}

Source: 2017 Population projected from 2006 National population census (NPC, 2006) [6].

\section{Sample Size}

The Taro Yamane Formula was used.

$$
\begin{aligned}
& n=\frac{N}{1+N(e) 2} \\
& n=\frac{91,822.92}{1+91,822.92(0.05) 2} \\
& n=\frac{91,822.92}{1+91,822.92(0.0025)} \\
& n=\frac{91,822.92}{959.17} \\
& n=399.6 \approx 400
\end{aligned}
$$

Based on this a total of 400 respondents was the sample size. Table 2 shows the percentage of questionnaire administration.

Table 2. Questionnaire Administration.

\begin{tabular}{|c|c|c|}
\hline LGA & Percentage (\%) & Sample Size \\
\hline Okobo & 32.25 & 129 \\
\hline Uruan & 42.11 & 168 \\
\hline Nsit Atai & 25.6 & 103 \\
\hline TOTAL & 100 & 400 \\
\hline
\end{tabular}

In administrating the questionnaire, quota system was used. The LGA's were given questionnaires based on their percentage contribution to the total population. Okobo was given $32.25 \%$ (129) of the questionnaires, Uruan was given $42.11 \%$ (168) and Nsit Atai was given 25.6\% (103) of the questionnaires respectively. A systematic sampling technique was employed in selecting households to be sampled.

Table 3. Community Residence of Respondents.

\begin{tabular}{|c|c|}
\hline Community of residence & Number of respondents \\
\hline Amamong & 88 \\
\hline Ebighi Eta & 9 \\
\hline Ekpene Ukim & 64 \\
\hline Esuk Inwang & 7 \\
\hline Idiaba & 90 \\
\hline Ikot Inyang & 4 \\
\hline Ikot Mkpo & 4 \\
\hline Ishiet Ekim & 22 \\
\hline Ndon Ebom & 74 \\
\hline Ndon Ekpe & 4 \\
\hline Nung Atai & 33 \\
\hline TOTAL & 400 \\
\hline
\end{tabular}

Source: Field data (2017).

Table 3 presents the communities where the respondents were drawn. A five kilometers $(5 \mathrm{~km})$ buffer was drawn around the lbom International airport and all the communities were listed according to buffers ( 1 km, 2 km, 3 km, 4 km, and 5 km). 
A buffer was used to delimit the study area to enable the research study the distance decay in the area of income. Ten percent of the communities were selected at random from each of the buffer levels. Ten percent is the minimum level for any sample to considered valid [8]. The buffer map is presented in figure 2 .

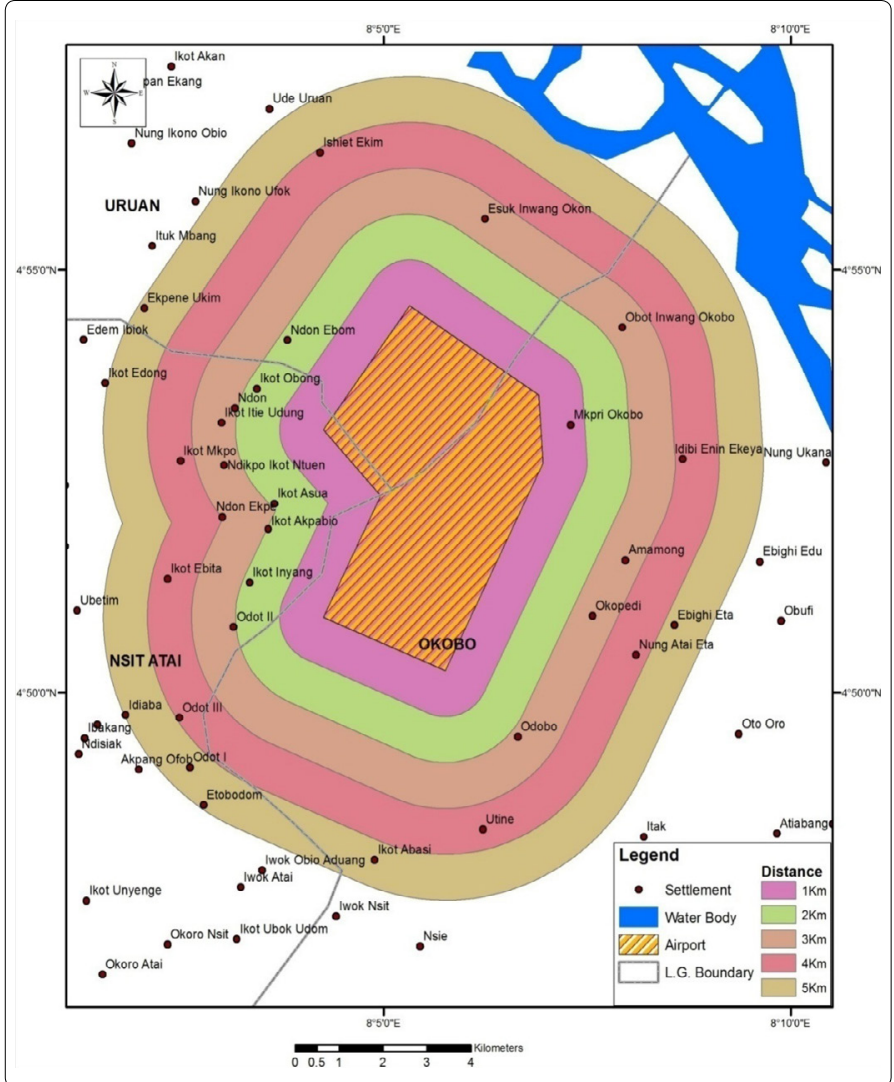

Figure 2. Buffer Map of Communities $5 \mathrm{~km}$ from the Airport.

\section{Method of Data Collection}

The following variables were sought for socio-economic information using structured questionnaires; socio-demographic information, employment, income, tourism and health.

Table 4. Socio-demographic information.

\begin{tabular}{|c|l|}
\hline Variable & Method of Data Collection \\
\hline Gender & Structured Questionnaire \\
\hline Marital status & Structured Questionnaire \\
\hline Levels of education & Structured Questionnaire \\
\hline Religion & Structured Questionnaire \\
\hline Community & Structured Questionnaire \\
\hline Employment Status & Structured Questionnaire \\
\hline Family Size & Structured Questionnaire \\
\hline
\end{tabular}

Table 5. Income

\begin{tabular}{|l|l|l|}
\hline Variable & Indicators & Method of Data Collection \\
\hline Income & $\begin{array}{l}\text { Monthly income of } \\
\text { respondents }\end{array}$ & $\begin{array}{l}\text { Questionnaire was used to collect income } \\
\text { range of respondents }\end{array}$ \\
\hline
\end{tabular}

\section{Method of Data Analysis}

Descriptive and inferential statistics were the major method of analysis used. Percentages, charts and maps were used to describe the extent of impact the airport has on income of the airport host communities. Data collected on each of the variables were mapped to indicate their strength with distance.

\section{Results}

\section{Impact of airport on income}

The study also investigated the impact of the Airport on the income of the Respondents and the results are presented in table 6.

Table 6. Monthly Mean Income of Respondents.

\begin{tabular}{|c|c|c|}
\hline Names & Distance & Mean Income (in Naira) \\
\hline Ndon Ebom & 2 & 30,637 \\
\hline Ekpene Ukim & 5 & 31,405 \\
\hline Ishiet Ekim & 4 & 32,944 \\
\hline Esuk Inwang & 3 & 20,000 \\
\hline Amamong & 3 & 37,117 \\
\hline Nung-Atai & 4 & 43115 \\
\hline Ebighi Eta & 5 & 28,200 \\
\hline Ikot Inyang & 2 & 40250 \\
\hline Idiaba & 5 & 22430 \\
\hline Ikot Mkpo & 4 & 20000 \\
\hline Ndon Ekpe & 2 & 20000 \\
\hline
\end{tabular}

Source: Field Data (2017)

The distribution as shown in table 6 indicated that the lowest mean monthly income was higher than the minimum wage in Akwa Ibom State. The presence of the Airport could be the reason for this difference. It can be thus inferred that the respondents benefit from other source of livelihood since communities at $4 \mathrm{~km}$ distance had the highest mean income.

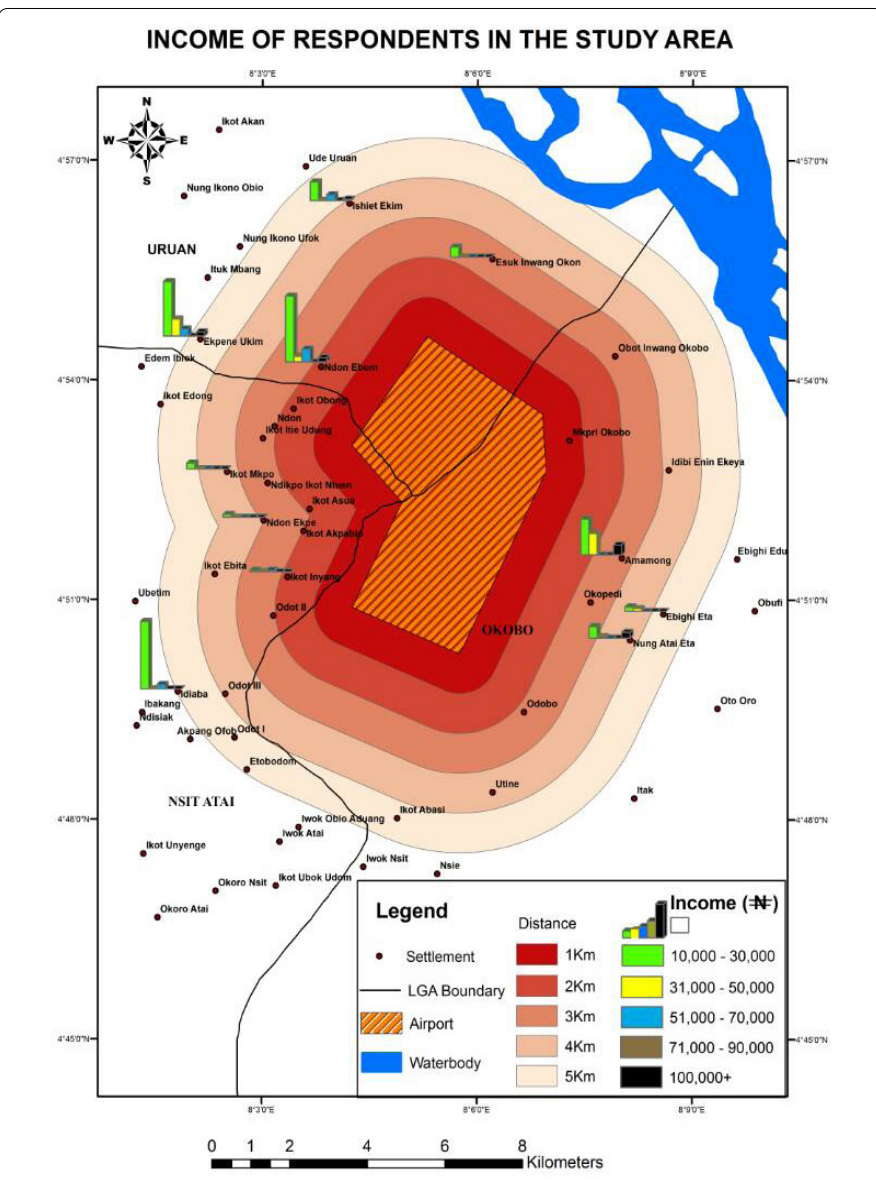

Figure 3. The income range of respondents with distance.

Figure 3 shows that there is no consistency in the pattern of income distribution of the host communities with distance, this refute the distance decay model. 
In Uruan L.G.A. the numbers of Respondents within income range of 10,000-30,000 are highest at $3 \mathrm{~km}$ and least at $4 \mathrm{~km}$ distance. The least number of respondents are within income range of 51,000-50,000 are found at the $3 \mathrm{~km}$ distance. Respondents within income range of $31,000-50,000$ are only found at $5 \mathrm{~km}$ buffer distance. In Nsit-atai L.G.A, respondents within the income range of 10,000-30,000 are highest at the 5 $\mathrm{km}$ buffer distance with other distances having very low numbers. Number of Respondents within the income range of 31,000- 50,000 are very low and are only found in $5 \mathrm{~km}$ buffer. In Okobo respondents within the income range of 10,000-30,000 declined with distance from $2 \mathrm{~km}$ to $4 \mathrm{~km}$ buffer distance. Respondents within the income range of $31,000-50,000$ are only found at $2 \mathrm{~km}$ distance.

\section{Test of hypothesis}

A certainty in the study was needed to affirm if Obong Victor Attah International Airport contributed significantly to the income of the selected host communities. Hence this hypothesis was tested.

$\mathrm{H}_{\mathrm{o}}=$ Airport does not significantly impact income

Table 7. Summary of Simple Linear Regression Analysis of the Impact of the Obong Victor Attah International Airport on Income.

\begin{tabular}{|l|l|l|l|l|l|l|l|}
\hline Indicator & $\mathrm{R}$ & $\mathrm{R}^{2}$ & ADJ R & STD ERR & SIG & $\mathrm{B}$ & $\mathrm{F}$ \\
\hline Income & .085 & 0.07 & -.103 & 8774.131 & 0.803 & -.085 & 0.066 \\
\hline
\end{tabular}

Analysis by Author (2017)

Information on the relationship between Airport and income is subjected to simple linear regression using SPSS version 20. The results indicated that the $R$ which was the correlation between the observed (Airport) and predicted dependent variables (Income) was low for Income (8.5\%) and the R-Square or coefficient of determination indicated that the Airport contributed poorly to Income (7\%). The magnitude and influence of these variables are shown by the $B$ values. The negative $B$ values for the variables (Income) indicate that airport does not make any positive contribution to income. The proportion of variance in the dependent variable (income) which was explained by the independent variable (Airport as represented by the distances from the Airport) is $-10.3 \%$.

Based on the low (weak) correlation indicated by the $R$ coefficient for income, it was concluded that Obong Victor Attah International Airport was not a major determinant of income in the host communities (Uruan, Okobo and Nsit-Atai LGA's of Akwa Ibom State).

\section{Discussion}

\section{Income impact of airport}

An assessment of the mean monthly income of respondents revealed that the residents of the Airport host communities had moderate income having mean income of 29,645 Naira which is above the minimum wage of AkwaIbom State. This moderate income could be attributed to the presence of the Airport. This result is in agreement with the study carried out by $\mathrm{ACl}$ [1] which exposed that European Airports contributed to income higher than the average income in the overall economy. However, an assessment of the income levels of respondents with distance show that income levels of respondents does not increase with distance this implies that Airport does not totally influence the income of the host communities and that the respondents could be engaged in other economic activities. This is supported by the $\mathrm{R}^{2}$ coefficient from the linear regression analysis that showed that Airport Contributed 7\% to Income.

\section{Conclusions}

The importance of economic growth, national development, and poverty reduction cannot be overemphasized. This had been enunciated in recent national and international policies, such as the Sustainable Development Goals (SDGs) and National Poverty Eradication Program (NAPEP), among others. However, it is evident that poverty reduction and propoor development strategies can benefit rural economy. It also recognizes the critical linkage of the sector in Africa with the rural economy. Hence, the availability of airport service is an important determinant of community's growth rate. The findings of the study showed that the Airport was not the major source of income for the host communities. This further implied that host communities have other sources of income other than the Airport.

\section{References}

1. ACI Europe. Economic Impact of European Airports: A Critical Catalyst to Economic Growth. Inter vistas Consulting Ltd, UK. 2015.

2. Huderek-Glapska S. The employment and Income benefits of airport operation on the county on transition. Scientific Journal of Logistics. 2013; 6(38): 1-34.

3. Inter VISTAS. Economic Impact of European Airports. 2015.

4. Luke R, Jackie W. Impact of South Africa's International Airports. Institute of transport and logistics studies, University of Johannesburg, South Africa. 2011; 120-137

5. Martin Associates. The local and regional Economic impacts of Milwaukee County's. General Mitchell International Airport. Preparation in corporation with Breitenbach Inc. for milankee county, UK. 2005.

6. National Population Census-NCP. Akwa Ibom State Population Census, National Population Census. Federal Republic of Nigeria. 2006.

7. Smith CDM. The Economic Impact of Commercial Airports in 2010. Prepared for Airports Council International - North America. 2006.

8. Udofia E. Applied Statistics with Multivariate Methods. Enugu: Immaculate Publishers. 2011; 357.

9. Weisbrod G, Weisbrod B. Measuring the Economic impacts of project and programs. Economic development research group. 1997; 1-11.

10. Smith W. South Carolina the economic impact of aviation. EDR Group and Franks and Associates. 2006. 